Jurnal Keperawatan Silampari

Volume 3, Nomor 2, Juni 2020

e-ISSN: 2581-1975

p-ISSN: 2597-7482

DOI: https://doi.org/10.31539/jks.v3i2.1160

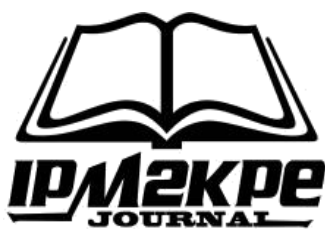

\title{
LIPID PROFILE DAN TEKANAN DARAH PADA WANITA DEWASA BERDASARKAN PEMERIKSAAN BMI DAN LP
}

\author{
Yunus Elon ${ }^{1}$, Denny Paul Ricky ${ }^{2}$ \\ Universitas Advent Indonesia ${ }^{1,2}$ \\ yunus.elon@unai.edu ${ }^{1}$
}

\begin{abstract}
ABSTRAK
Penelitian ini bertujuan untuk menganalisa hubungan BMI, LP (lingkar pinggang) dengan lipid profile dan tekanan darah. Desain penelitian mengunakan metode kuantitatif, dengan pendekatan deskriptif korelasional. Hasil penelitian memperlihatkan, rerata BMI responden 28,58 atau obesitas dan lingkar pinggang 91,53 kategori tinggi, sementara tekanan darah sistolik dan diastolik termasuk dalam kategori hipertensi grade 1 dengan nilai 139,05 dan 89,03 mmHg. Lipid profile (total kolesterol dan trigliserida berada dalam batas normal dengan rerata 183,08 dan $94,93 \mathrm{mg} / \mathrm{dl}$ ). Analisis bivariate BMI dan LP dengan tekanan darah sistolik dan lipid profile dengan $p$-value $>.05$ dan $p$ value <.05 untuk BMI dan LP terhadap tekanan darah diastolik. Simpulan, terdapat hubungan yang signifikan antara BMI dan LP terhadap tekanan darah diastolik namun tidak terdapat hubungan yang signifikan terhadap tekanan darah sistolik dan lipid profile.
\end{abstract}

Kata Kunci: BMI, LP, Lipid Profile, Tekanan Darah

\section{ABSTRACT}

This study aims to analyze the relationship between BMI, WC (waist circumference) with lipid profile, and blood pressure. The research design uses quantitative methods, with a correlational descriptive approach. The results showed that the mean BMI of respondents was 28.58 or obesity and waist circumference 91.53 were in the high category. At the same time, systolic and diastolic blood pressure were included in hypertension grade 1, with values of 139.05 and $89.03 \mathrm{mmHg}$. Lipid profile (total cholesterol and triglycerides are within normal limits with a mean of 183.08 and 94.93 $\mathrm{mg} / \mathrm{dl}$. Bivariate analysis of BMI and LP with systolic blood pressure and lipid profile with p-value> .05 and p-value <.05 for BMI and LP on diastolic blood pressure Conclusion, There is a significant relationship between BMI and LP on diastolic blood pressure, but there is no meaningful relationship to systolic blood pressure and lipid profile.

Keywords: BMI, Waist Circumference, Lipid Profile, Blood Pressure

\section{PENDAHULUAN}

Peningkatan tekanan darah atau hipertensi masih menjadi faktor penyebab utama dari penyakit jantung dan pembuluh darah, dimana kondisi tersebut akan semakin memburuk jika disertai dengan peningkatan profil lemak dalam darah. Penelitian yang dilakukan di India terhadap 183,335 subjek, baik pria maupun wanita didapati bahwa 1 
dari 3 orang dewasa mengalami peningkatan tekanan darah atau hipertensi, (Ramakrishnan et al., 2019). Survey yang dilakukan di Indonesia, terhadap 29965 menunjukkan hal yang sama. Responden berusia 18 tahun keatas dengan rata-rata usia 43,3. Memperlihatkan prevalensi hipertensi sebesar $33,4 \%$ atau $1 / 3$ dari populasi Indonesia menderita hipertensi, dimana, insiden pada wanita lebih tinggi dibanding pria dengan persentasi $35,4 \%$ berbanding 31,0\%. Diantara mereka yang mengalami hipertensi hanya $42,9 \%$ yang sadar, $11,5 \%$ mendapatkan pengobatan dan $14,3 \%$ dapat dikontrol, analisis juga menunjukkan hubungan yang signifikan antara peningkatan BMI dengan kejadian hiperetnsi (Peltzer, 2018). Data Kemenkes yang dirilis tahun 2019 memperlihatkan angka yang lebih besar dimana jumlah penduduk indonesia yang menyandang status hipertensi sebesar 63.309 .620 orang atau $42,17 \%$ menderita hipertesnsi dengan jumlah kematian mencapai 427.218 kematian pertahun atau 1.171 perhari (Kementrian Kesehatan Republik Indonesia, 2019).

Lebih jauh penelitian yang dilakukan terhadap 112 pasangan suami istri didapati bahwa prevalensi hipertensi sebesar 49,1\% atau hampir setengah dari pasangan tersebut mengalami hipertensi. Hasil penelitian tersebut juga memperlihatkan 54,4\% pada wanita berbanding $43,7 \%$ pria, atau wanita lebih tinggi dibandingkan pria, hasil analisis memperlihatkan bahwa wanita lebih banyak yang overweight, obesitas dan abdominal obesitas atau memiliki lingkar pinggang yang lebih tinggi (Diana et al., 2018). Penelitian yang dilakukan disalah satu perguruan tinggi swasta dibandung, terhadap mahasiswa (pria) tingkat 1-4, didapati $44 \%$ mengalami peningkatan tekanan darah serta 36\% mengalami peningkatan BMI atau masuk kategori obesitas (Malinti, Elon, 2019). Sementara itu penelitian yang dilakukan disalah satu desa di kabupaten Bandung Barat terhadap wanita dewasa, memperlihatkan angka obesitas yang cukup mencengangkan, dimana $42,9 \%$ masuk dalam kategori gemuk dan 31,1\% obesitas atau dengan kata lain 73,3\% mengalami peningkatan berat badan (Riris, Elon, 2019) .

Dengan tingginya angka kejadian hipertensi yang ada di Indonesia namun upaya untuk mengendalikan hipertensi tersebut masih kurang, perlu adanya berbagai macam upaya yang bisa dilakukan untuk mengendalikan angka kejadian hipertensi yang tinggi tersebut sehingga dapat menekan angka hipertensi (Andri et al., 2018; Sartika et al., 2018).

Studi terhadap 1.727.411 partisipan memperlihatkan korelasi yang signifikan antar peningkatan BMI dengan kejadian hipertensi (Linderman et al., 2018). Hasil yang sama dengan penelitian tersebut yang dilakukan di desa Kinamang terhadap 89 subjek menyimpulkan terdapat hubungan yang signifikan antara BMI dengan tekanan darah, artinya semakin tinggi tekanan darah seseorang semakin tinggi BMI-nya, dengan $p$ value 0,001 <0,05, (Tendean, 2019). Merujuk kepada penelitian-penelitain tersebut maka, hipertensi yang disertai dengan obesitas dan hyperlipidemia menambah resiko penyakit jantung dan pembuluh darah (Ariyanti, Besral, 2019). Terdapat hubungan yang signifikan antara kolesterol dengan tekanan darah dengan $\mathrm{p}=0.04$ (Lina et al., 2020).

Lebih jauh analisis terhadap obesitas sentral atau peningkatan lingkar pinggang terhadap tekanan darah, dimana mereka yang mengalami obesitas sentral berpeluang 3,63 (95\% CI 1,52-8,68) mengalami hipertensi dibanding mereka yang tidak memiliki obesitas central dengan $p$-value 0.003 ) penelitian ini dilakukan pada kelompok usia 2565 tahun pada 107 responden (Rahma, Gusrianti, 2018).

Berdasarkan fakta-fakta ilmiah tersebut, penelitian tentang hubungan antara BMI, lingkar pinggang terhadap lipid profile dan hipertensi sudah pernah dilakukan dan berfokus pada salah satu variabel saja, namun penelitian ini menghubungkan antara BMI, lingkar pinggang dengan lipid profile dan tekanan darah, penelitian ini juga lebih 
menekankan pada responden wanita dewasa usia 26-46 tahun dimana proses pengambilan data dilakukan setelah pasien berpuasa selama 8-10 jam, kemudian data BMI, lingkar pinggang, tekanan darah serta lipid profile di ambil pada saat responden dalam keadaan berpuasa.

\section{METODE PENELITIAN}

Metode yang digunakan dalam penelitian ini adalah metode kuantitatif dengan pendekatan descriptive correlational, yang menghubungakan antara satu variable dengan variable yang lain. Penelitian ini mecobah untuk menganlisa hubungan antara BMI, LP dengan lipid profile dan tekanan darah. Wanita dewasa awal dan akhir atau usia 26-45 tahun merupakan populasi yang dipilih untuk berpartisipasi dalam penelitian ini. Dimana penelitian ini dilakukan di RW 13, desa cihanjuang rahayu, Kecamatan Parongpong. Dari populasi yang ada diambil sampel berdasarkan kriteria inklusi antara lain, warga tetap yang berdomisili di RW 13, jenis kelamin wanita dengan rentang usia 26-45 tahun, berbadan sehat, mereka yang mengalami ganguan kesehatan tidak diiukutkan dalam penelitian ini. Sampel ditetapkan menggunakan rumus slovin berdasarkan jumlah populasi wanita dewasa yaitu 58 responden.

Penelitian ini telah mendapatkan surat ijin dari kepala puskesmas parongpong, kepala RW 13 dan telah mendapatkan sertifikat layak etik dengan nomor: 025/KEPKFIK.UNAI/EC/X /19. Peneliti mendatangai responden dari rumah kerumah, responden yang memenuhi kriteria dan bersedia berpartisipasi dalam penelitian ini, diberikan informed consent dan setelah memahami responden membubuhkan tanda tangan persetujuan. Responden yang bersedia diminta untuk berpuasa selama 8-10 jam yang dimulai pada jam 10 malam. Keesokan harinya mereka datang diaula untuk pengambilan darah oleh petugas laboratorium.

Tabel. 1

Klasifikasi BMI dan LP pada Wanita

\begin{tabular}{ccc}
\hline & Rentang & Kategori \\
\hline \multirow{2}{*}{ BMI } & $<18,5$ & Underweight \\
& $18,5-24,9$ & Normal \\
& $25-29,9$ & Overweight \\
\multirow{2}{*}{ LP wanita } & $\geq 30$ & Obesitas \\
& $<80 \mathrm{~cm}$ & Normal \\
& $\geq 80 \mathrm{~cm}$ & Obesitas \\
\hline
\end{tabular}

Sebelum pengambilan darah dilakukan pengukuran berat badan dengan timbangan digital yang terkalibrasi dan tinggi badan dengan stature meter. Serta lingkar pinggang. Hasilnya digunakan untuk menghitung BMI yang diklasifikasikan berdasarkan WHO 2016.

Tabel. 2

Klaifikasi Tekanan Darah pada Orang Dewasa

\begin{tabular}{lll}
\hline Sistolik mmHg & Diastolic mmHg & Keterangan \\
\hline$<120$ & $<80$ & Normal \\
$120-129$ & $<80$ & Elevated \\
$130-139$ & $80-89$ & HTgrade 1 \\
$\geq 140$ & $\geq 90$ & HT grade 2 \\
\hline
\end{tabular}


Tekanan darah diukur setelah responden beristirahat selam 5 menit dengan menggunakan alat ukur tekanan darah digital yang terkalibrasi.

Tabel. 3

Klasifikasi Lipid Profile

\begin{tabular}{ll}
\hline Kategori & Nilai mg/dl \\
\hline Total Kolesterol & \\
Normal & $<200 \mathrm{mg} / \mathrm{dL}$ \\
Batas tinggi & $200-239 \mathrm{mg} / \mathrm{dL}$ \\
Tinggi & $\geq 240 \mathrm{mg} / \mathrm{dL}$ \\
Trigliserida & \\
Normal & $<150 \mathrm{mg} / \mathrm{dL}$ \\
Batas Tinggi & $150-199 \mathrm{mg} / \mathrm{dL}$ \\
Tinggi & $200-499 \mathrm{mg} / \mathrm{dL}$ \\
Sangat Tinggi & $>500 \mathrm{mg} / \mathrm{dL}$ \\
\hline
\end{tabular}

Selanjutnya, darah dari pembuluh darah vena diambil oleh petugas laboratorium dengan menggunakan vacuum spuit sekitar $3 \mathrm{ml}$ dan analisis lipid profile dianalisa menggunakan mesin cobas integra yang telah dikalibrasi.

Dari 58 responden yang hadir. Hanya 42 yang puasa 8-10 jam, dan ada dua yang memiliki riwayat DM. Selanjutnya data dianalisa dengan menggunakan deskriptif analisis berupa persentasi, mean serta analisis korelasi untuk melihat hubungan antara BMI, LP dengan Lipid profile dan tekanan darah. Sebelum uji korelasi dilakukan terlebih dahulu dilakukan uji normalitas Shapiro-Wilk menunjukkan data berdistribusi normal $(\mathrm{p}>.05)$. Kecuali Trigliserida $(\mathrm{p}<.05)$ atau tidak berdistribusi normal. Sehingga uji korelasi antara BMI, LP dengan tekanan darah dan total kolesterol menggunakan uji Pearson product moment dan untuk BMI, LP dengan Trigliserida menggunakan uji korelasi spearman's rho.

\section{HASIL PENELITIAN}

Tabel. 4

Distribusi Subjek Berdasarkan, Usia, Status Pernikahan, Pendidikan, Pekerjaan, BMI, LP, Tekanan Darah dan Lipid Profile

\begin{tabular}{cccc}
\hline Variabel & Kategori & Frekuensi & Persentasi \\
\hline Usia & Dewasa awal & 17 & $42,5 \%$ \\
& Dewasa Pertengahan & 23 & $57,5 \%$ \\
\hline Status pernikahan & Menikah & 31 & $77,5 \%$ \\
& Janda & 9 & $22,5 \%$ \\
\hline Pekerjaan & IRT & 21 & $52,5 \%$ \\
& Karyawan & 19 & $47,5 \%$ \\
\hline Pendidikan & SD & 19 & $47,5 \%$ \\
& SMP & 17 & $42,5 \%$ \\
& SMA & 4 & $10 \%$ \\
\hline BMI & Gemuk & 6 & $15 \%$ \\
& Obesitas & 34 & $85 \%$ \\
\hline Lingkar Pinggang & & & \\
& Normal & 8 & $20 \%$ \\
& Tinggi & 32 & $80 \%$ \\
\hline TD Sistolik & Normal & 7 & $17,5 \%$ \\
& Meningkat & 5 & $12,5 \%$ \\
& HT grade 1 & 10 & $25 \%$ \\
& HT Grade 2 & 18 & $45 \%$ \\
\hline
\end{tabular}




\begin{tabular}{cccc}
\hline TD Diastolik & Normal & 11 & $27,5 \%$ \\
& Meningkat & 1 & $2,5 \%$ \\
& HT grade 1 & 8 & $20 \%$ \\
& HT Grade 2 & 20 & $50 \%$ \\
\hline Total kolesterol & Normal & 30 & $75 \%$ \\
& Meningkat & 9 & $22,5 \%$ \\
& Tinggi & 1 & $2.5 \%$ \\
\hline Triglicerida & Normal & 38 & $95 \%$ \\
& Batas normal tinggi & 2 & $5 \%$ \\
\hline Sumber: data primer $(2019)$ & & &
\end{tabular}

Sumber: data primer (2019)

Tabel 4 menunjukkan bahwa 57,5\% masuk dalam katerori dewasa pertengahan dan $42,5 \%$ dewasa awal. Status pernikahan memperlihatkan 77,5\% menikah dan 22,5\% berstatus janda. Dari segi pekerjaan sebanyak 52,5\% ibu rumah tangga dan 47,5 karyawan. Berdasarakan pendidikan, sebanyak 47,5\% SD, 42,5\% SMP dan 10\% SMA. Data body mass index atau indeks masa tubuh sebayak $85 \%$ obesitas, dan $15 \%$ dalam kategori gemuk. Untuk lingkar pinggang, sebanyak 80\% tinggi dan 20\% normal. Sementara untuk tekanan darah dan lipid profile seperti berikut ini; tekanan darah sistolik $82,5 \%$ memiliki tekanan darah diatas normal dan 17,5\% dengan tekanan darah normal. Untuk diastolik sebanyak $72,5 \%$ diatas normal dan $27,5 \%$ normal. Total kolesterol, $75 \%$ normal dan $25 \%$ mengalami peningkatan. Untuk trigliserida, $95 \%$ normal dan hanya $5 \%$ yang mengalami peningkatan.

Tabel. 5

Rerata BMI, LP, Lipid Profile Serta Tekanan Darah Sistolik dan Diastolik

\begin{tabular}{lccc}
\hline Variabel & Mean & SD & Interpretasi \\
\hline BMI & $28,58 \mathrm{~kg} / \mathrm{m}^{2}$ & 4,73 & Obesitas \\
LP & $91,53 \mathrm{~cm}$ & 10,98 & Tinggi \\
Total Kolesterol & $183,08 \mathrm{mg} / \mathrm{dl}$ & 27,58 & Normal \\
Triglicerida & $94,93 \mathrm{mg} / \mathrm{dl}$ & 33,37 & Normal \\
TD Sistolik & $139,05 \mathrm{mmHg}$ & 19,33 & Hipertensi grade 1 \\
TD Diastolik & $89,03 \mathrm{mmHg}$ & 13,19 & Hipertensi grade I \\
\hline
\end{tabular}

$\mathrm{BMI}=$ Body mass index, $\mathrm{TD}=$ Tekanan darah, $\mathrm{LP}=$ Lingkar Pinggang

Tabel 5 memperlihatkan rerata deskriptif analisis terhadap 40 responden dalam penelitian ini yang mencakup BMI, LP, Lipid Profile dan tekanan darah. Adapun rerata seperti berikut; BMI $28,58 \mathrm{~kg} / \mathrm{m}^{2}$ yang diinterpretasikan sebagai obesitas. Lingkar pinggang sebesar $91,53 \mathrm{~cm}$ yang masuk dalam kategori tinggi, Total kolesterol dan trigliserida $183,08 \mathrm{mg} / \mathrm{dl}$ dan $94,93 \mathrm{mg} / \mathrm{dl}$ yang masuk dalam kategori normal. Tekanan darah sistolik $139,05 \mathrm{mmHg}$ dan $89,03 \mathrm{mmHg}$ yang diinterpretasikan sebagai hipertensi grade 1.

Tabel. 6

Hubungan BMI dan Lingkar Pinggang dengan Tekanan Darah, Lipid Profile dengan Tekanan Darah

\begin{tabular}{lccc}
\hline Variabel & $\mathrm{R}$ & Sig-2tailed & Interpretasi \\
\hline BMI & .135 & .408 & Tidak signifikan \\
TD Sistolik & & & Signifikan \\
BMI & .333 & .036 & \\
TD Diastolik & & & \\
\hline
\end{tabular}




\begin{tabular}{lccc}
\hline BMI & .112 & .491 & Tidak Signifikan \\
Total Kolesterol & & .298 & Tidak signifikan \\
$\begin{array}{l}\text { BMI } \\
\text { Triglicerida }\end{array}$ & .169 & .496 & Tidak Signifikan \\
\hline $\begin{array}{l}\text { Lingkar Pinggang } \\
\text { TD Sistolik }\end{array}$ & .111 & .050 & Signifikan \\
$\begin{array}{l}\text { Lingkar Pinggang } \\
\text { TD Diastolik }\end{array}$ & .312 & .491 & Tidak Signifikan \\
\hline $\begin{array}{l}\text { Lingkar Pinggang Total } \\
\text { Kolesterol }\end{array}$ & .112 & .366 & Tidak Signifikan \\
$\begin{array}{l}\text { Lingkar Pinggang } \\
\text { Triglicerida }\end{array}$ & .147 & & \\
\hline BMI= Body mass index, TD= Tekanan darah, Significant at $\alpha<.0 .05$ &
\end{tabular}

Tabel 6 memperlihatkan hubungan antara BMI, LP terhadap lipid profile dan tekanan darah. Hubungan antara BMI dengan tekanan darah sistolik p-value .408 (r.135) yang diinterpretasikan hubungan yang tidak signifikan dengan keeratan hubungan sangat rendah dan BMI dengan diastolik p-value .036 (r.333) diinterpretasikan hubungan yang signifikan dengan tingkat keeratan hubungan rendah. BMI dengan Total kolesterol dan trigliserida p-value .491 (r.112) dan .298 (r.169) yang diinterpretasikan tidak signifikan dengan keeratan hubungan sangat rendah. Sementara untuk hubungan antara LP dengan tekanan darah sistolik p-value .496 (r.111) yang diinterpretasikan hubungan tidak signifikan dengan keeratan hubungan sangat rendah. Terdapat hubungan yang signifikan antara LP dengan tekanan darah diastolik p-value .050 (r.312) dengan tingkat keeratan hubungan rendah. Untuk lingkar pinggang dengan total kolesterol dan trigliserida dengan p-value .491 (r.112) dan .366 (r.147) yang diinterpretasikan tidak ada hubungan signifikan dengan keeratan hubungan sangat rendah.

\section{PEMBAHASAN}

\section{Karakteristik Responden}

Hasil penelitian berdasarkan karakteristik responden memperlihatkan distribusi mayoritas berdasarkan usia yaitu 57,5\% dewasa pertengahan, status pernikahan $77,5 \%$ menikah, pekerjaan 52,5\% IRT dan pendidika 47,5\% SD. Untuk BMI $85 \%$ obesitas, LP $80 \%$ tinggi, tekanan darah sistolik $45 \%$ hipertensi grade 2, tekanan darah diastolik $50 \%$ hipertensi grade 2 dan total kolesterol $75 \%$ normal serta $95 \%$ memeiliki trigliserida yang normal. Usia merupakan salah satu faktor peningkatan tekanan darah dan profil lemak dalam darah hasil penelitian yang dilakukan oleh Lusiana, Widayanti, Mustika, \& Andiarna (2019) terdapat hubungan yang signifikan antara usia dan tekanan darah khususnya sistolik dengan $\mathrm{p}=.007$, yang menyimpulkan semakin tua seseorang semakin tinggi tekanan darahnya.

Wanita yang telah menikah lebih cenderung mengalami kegemukan atau peningkatan berat badan di banding dengan pria, dimana untuk wanita yang telah menikah, overweight $61,1 \%$ berbanding $38,9 \%$ pada pria yang telah menikah begitu juga dengan obesitas $85,7 \%$ banding 14,3\%, (Diana et al., 2018). Hasil tersebut sejalan dengan temuan penelitian terhadap 120 wanita dewasa, subjek yang telah menikah menunjukkan angka obesitas sentral yang lebih tingg namun tingkat pendidikan, pekerjaan tidak memiliki korelasi dengan kejadian obesitas sentral (Triyanti, Ardila, 2019). Penelitian yang dilakukan di Aceh terhadap 25 wanita dewasa memperlihatkan rata-rata BMI 27,2 yang tergolong obese atau gemuk, (Fitri et al., 2016). Hasil 
penelitian ini juga sejalan dengan penelitian yang dilakukan oleh Ghomari-Boukhatem et al., (2017) dimana obesitas atau peningkatan BMI memiliki hubungan yang kuat dengan tekanan darah tinggi dan gangguan profil lemak darah dan berbagai penyakit tidak menular lainnya.

\section{Rerata BMI, Lingkar Pinggang, Lipid Profile dan Tekanan Darah Responden}

Table 5 memberikan gambaran rata-rata BMI $28,58 \mathrm{~kg} / \mathrm{m}^{2}$, lingkar pinggang sebesar $91,53 \mathrm{~cm}$, total kolesterol dan trigliseride 183,08 dan 94,93 mg/dl serta tekanan darah sistolik 139,05 dan 89,03 mmHg. Kelebihan berat badan dan kegemukkan meningkat pada perempuan diusia produktif yang mana kondisi tersebut mengakibatkan rasiao tinggi dan berat badan tidak seimbang serta peningkatan rasio lingkar pinggang dan panggul, (Yaya, Ghose, 2019). Penambahan berat badan yang terjadi pada wanita setelah menikah disebabkan oleh kurang mengontrol diet, tidak lagi berfokus merawat diri karena harus merawat suami dan anak-anak. Faktor lain yaitu kehamilan, perubahan hormone dan jarang berolahraga (Iswandiari, 2017; Sarma et al., 2016). Penelitian terhadap 96 wanita usia subur, dimana 48 obesitas dan 48 normal. Hasil penelitian tersebut mengambarkan faktor-faktor yang mempengaruhi kejadian obesiats yaitu; aktifitas fisik dengan p-value 0.001, keturunan dimana yang memiliki keturunan obesitas 9 kali lebih besar resiokonya disbanding yang tidak obesitas. Pola makan juga menjadi pemicu dimana subjek yang pola makannya kurang baik 10 kali lebih beresiko mengalami obesitas namu tidak ada hubungan antara kejadian obesitas dengan kesehatan mental (Raudhatun, 2020). Walaupun wanita dewasa dalam penelitian ini mengalami obesitas, hal ini tidak berpengaruh pada total kolesterol dan trigliserida darah. Kedua gambaran lemak darah ini masih dalam batas normal, namun terlihat bahwa wanita dalam penelitian ini memiliki tekanan darah yang tinggi.

Hasil penelitian yang dilakukan terhadap 136 orang dewasa pria dan wanita didapati subjek yang memiliki BMI normal akan lebih banyak yang memiliki tekanan darah baik sistolik maupun diastolik dalam batas normal. Dilain pihak subjek yang memiliki BMI dengan kategori overweight dan obesitas memiliki tekanan darah yang lebih tinggi. Hasil tersebut memberikan gambaran bahwa semakin tinggi BMI maka semakin tinggi pula tekanan darah, baik sistolik maupun diastolik (Hutagaol, Malinti, 2020).

\section{Hubungan antara BMI, LP terhadap Lipid Profile dan Tekanan Darah}

Hasil uji correlation pada table 6 menunjukkan tidak ada hubungan yang signifikan antara, BMI dengan tekanan darah sistolik, BMI dengan lipid profile (total kolesterol dan triglyceride), lingkar pinggang dengan tekanan darah sistolik dan lingkar pinggang dengan lipid profile (total kolesterol dan trigliserida) dengan nilai $p$-value $>$.05. Terdapat hubungan yang signifikan antara BMI dengan diastolik dan Lingkar pinggang dengan diastolik dimana nilai p-value <.05. Hasil penelitian ini sejalan dengan penelitian yang dilakukan oleh (Lusiana et al., 2019) dimana tidak tedapat hubungan antara index masa tubuh dengan tekanan darah dan cholesterol.

Namun tidak adanya hubungan antara BMI dengan total kolesterol dan trigliserida dalam penelitian ini bertentangan dengan hasil penelitian yang menyatakan bahwa obesitas berhubungan dengan profil lipid darah (Eslami et al., 2019; Lin et al., 2019). Trigliserida berhubungan dengan BMI dan lemak tubuh, dan total kolesterol berhubungan positif dengan lingkar pinggang, namun memiliki hubungan negatif dengan lemak tubuh (Telles et al., 2018). Sejalan dengan penelitian terhadap 99 
responden pria dan wanita, didapati hubungan yang signifikan antara BMI dengan lipid profile yang mencakup total kolesterol, HDL- kolesterol, LDL-kolesterol dan trigliserida dengan $p$-value <.05, (Humaera, Sukandar \& Rachmawati, 2017)

Dengan demikian terkadang hasil total kolesterol normal karena LDL tinggi namun HDL rendah. Penjelasan lain menunjukkan bahwa LDL kolesterol tidak berhubungan dengan obesitas. Menurunkan berat badan meningkatkan LDL. Tingginya LDL lebih dipengaruhi oleh usia dibanding BMI (Laclaustra et al., 2018). Sehingga bila LDL rendah pada BMI yang tinggi sedangkan HDL juga rendah maka total kolesterol tidak terpengaruh oleh kondisi obesitas.

Dilain pihak, antara BMI dan lingkar pinggang dengan tekanan darah khususnya diastolik memiliki hubungan yang signifikan. Beberapa penelitian membuktikan bahwa BMI dan lingkar pinggang mempengaruhi tekanan darah, seperti penelitian yang dilakukan terhadap 25 pria dewasa dibandung memperlihatakan hubungan yang signinifikan antara BMI dengan tekanan darah sistolik dan diastolik (Malinti, Elon, 2019). Nilai tekanan darah sistolik maupun diastolic meningkat secara signifikan seiring dengan peningkatan level BMI. Pengaruh lingkar pinggang lebih nyata dibanding BMI pada tekanan darah (Alhawari et al., 2018; Duc et al., 2018; Landi et al., 2018; Son et al., 2017).

Mekanisme yang menjadi dasar perubahan tekanan darah ini cukup kompleks termasuk meningkatnya aktifitas system saraf simpatis melalui aksi hiperleptinemia dan hiperinsulinemia. Selanjutnya, disfungsi endotel dan kerusakan pembuluh darah yang disebabkan oleh status inflamasi kronik, stress oksidatif yang berlanjut vasokonstriksi pembuluh darah dibarengi retensi cairan oleh aktifitas renin-angiotnesin-aldosteronsystem (RAAS). Sementara obesitas meningkatkan tekanan darah, menurunkan berat badan berhasil merunkan tekanan darah. Adalah penting bagi penderita hipertensi untuk melakukan diet dan perubahan pada gaya hidup sebagai upaya menurunkan berat badan (Fantin et al., 2019; Roush, 2019).

\section{SIMPULAN}

BMI 40 wanita dewasa masuk dalam kategori gemuk dan obesitas, sedangkan lingkar pinggang $80 \%$ tinggi hal ini berbanding lurus dengan hasil BMI. Tekanan darah sistolik dan diastolic memperlihatkan mayoritas responden memiliki peningkatan tekanan darah, baik sistolik maupun diastolik dan mayoritas responden memiliki kadar lipid profile yang normal. Tidak ada hubungan yang signifikan antara BMI, LP dengan tekanan darah sistolik dan lipid profile, dan terdapat hubungan yang singnifikan antara BMI dan LP terhadap tekanan darah diastolic.

\section{SARAN}

\section{Bagi Pelayanan}

Pendidikan kesehatan perlu menjadi bagian integral dalam pelayanan kesehatan masyarakat melalui perawat, bidan dan kader-kader kesehatan dalam mengedukasi masyarakat pentingnya menjaga tekanan darah dan BMI dalam batas normal, mengingat kedua faktor tersebut sangat berpengaruh kepada kesehatan jantung dan pembuluh darah.

\section{Bagi Peneliti Selanjutnya}

Untuk penelitian selanjutnya perluh menambahkan jumlah responden serta melibatkan berbagai kelompok usia dan jenis kelamin sehingga bisa memberikan gambaran yang menyeluruh. 
Tingkat kejadian hipertensi dan obesitas sangat tinggi dalam populasi ini, sehingga informasih bisa digunakan sebagai data awal untuk melakukan survei tekanan darah serta dapat digunakan untuk menentukan intervensi yang dapat dilakukan dalam penanganan tekanan darah.

\section{DAFTAR PUSTAKA}

Alhawari, H. H., Al-Shelleh, S., Alhawari, H. H., Al-Saudi, A., Aljbour Al-Majali, D., Al-Faris, L., \& Alryalat, S. A. (2018). Blood Pressure and Its Association with Gender, Body Mass Index, Smoking, and Family History among University Students. International Journal of Hypertension, 2018. https://doi.org/10.1155/2018/4186496

Andri, J., Waluyo, A., Jumaiyah, W., \& Nastashia, D. (2018). Efektivitas Isometric Handgrip Exercise dan Slow Deep Breathing Exercise terhadap Perubahan Tekanan Darah pada Penderita Hipertensi. Jurnal Keperawatan Silampari, 2(1), 371-384. https://doi.org/10.31539/jks.v2i1.382

Ariyanti, R., \& Besral, B. (2019). Dyslipidemia Associated with Hypertension Increases the Risks for Coronary Heart Disease: A Case-Control Study in Harapan Kita Hospital, National Cardiovascular Center, Jakarta. Journal of Lipids, 2019, 1-6. https://doi.org/10.1155/2019/2517013

Diana, R., Nurdin, N. M., Anwar, F., Riyadi, H., \& Khomsan, A. (2018). Risk Factors of Hypertension among Adult in Rural Indonesia. J. Gisi Pangan, 13(12), 111116. https://doi.org/10.25182/jgp.2018.13.3.111-116

Duc, N. N., Van, N. B., Vo, H. L., Do, N. K., Anh, H. N. S., Minh, H. T., Tuan, N. T., Duy, T. M., Thu, H. T. T., Chu-Dinh, T., \& Chu, D. (2018). Impact of Body Mass Index and Waist Circumference on Blood Pressure: A Cross-Sectional Survey in a Population Living in the Vietnam Northern Mountainous. Diabetes Metb Syndr, 13(2), 1399-1404. https://doi.org/doi: 10.1016/j.dsx.2019.02.015

Eslami, O., Shahraki, M., \& Shahraki, T. (2019). Obesity Indices in Relation to Lipid Abnormalities among Medical University Students in Zahedan, South-East of Iran. Int J Prev Med, 10(15). https://doi.org/doi: 10.4103/ijpvm.IJPVM_177_17

Fantin, F., Giani, A., Zoico, E., Rossi, A. P., Mazzali, G., \& Zamboni, M. (2019). Weight Loss and Hypertension in Obese Subjects. Nutrients, 11(7). https://doi.org/10.3390/nu11071667

Fitri, Y., Mulyani, N. S., Fitrianingsih, E., \& Suryana, S. (2016). Pengaruh Pemberian Aktifitas Fisik (Aerobic Exercise) terhadap Tekanan Darah, IMT dan RLPP pada Wanita Obesitas. Action: Aceh Nutrition Journal, 1(2), 105. https://doi.org/10.30867/action.v1i2.19

Hutagaol, Agnes Oktaviana; Malinti, E. (2020). Obesitas dan Tekanan Darah pada Orang Dewasa Usia 18-50 Tahun di Kampung Mokla. CHMK Nursing Scientific Journal, 4(2), 261-267

Iswandiari, Y. (2017). 7 Penyebab Wanita jadi gemuk setelah menikah. Hello Sehat

Kementrian Kesehatan Republik Indonesia. (2019). Hari Hipertensi Dunia 2019: Know Your Number, Kendalikan Tekanan Darahmu dengan CERDIK

Laclaustra, M., Lopez-Garcia, E., Civeira, F., Garcia-Esquinas, E., Graciani, A., Guallar-Castillon, P., Banegas, J. R., \& Rodriguez-Artalejo, F. (2018). LDL Cholesterol Rises with BMI Only in Lean Individuals: Cross-Sectional U.S. And Spanish representative data. Diabetes Care, 41(10), 2195-2201. https://doi.org/10.2337/dc18-0372 
Landi, F., Calvani, R., Picca, A., Tosato, M., Martone, A. M., Ortolani, E., Sisto, A., D’angelo, E., Serafini, E., Desideri, G., Fuga, M. T., \& Marzetti, E. (2018). Body Mass Index is Strongly Associated with Hypertension: Results from the Longevity Check-Up 7+ Study. Nutrients, 10(12), 1-12. https://doi.org/10.3390/nu10121976

Lin, L. Y., Hsu, C. Y., Lee, H. A., Tinkov, A. A., Skalny, A. V., Wang, W. H., \& Chao, J. C. J. (2019). Gender Difference in the Association of Dietary Patterns and Metabolic Parameters with Obesity in Young and Middle-Aged Adults with Dyslipidemia and Abnormal Fasting Plasma Glucose in Taiwan. Nutrition Journal, 18(1), 1-14. https://doi.org/10.1186/s12937-019-0503-x

Lina, M., Kumalasari, F., Kusumawati, E., Andyarini, E. N., Hidayati, S., \& Hidayati, S. (2020). Hubungan Kadar Kolesterol dengan Hipertensi pada Pegawai di Fakultas Psikologi dan Kesehatan UIN Sunan Ampel. Indonesian Journal for Health Science, 4(1), 10-15

Linderman, G. C., Lu, J., Lu, Y., Sun, X., Xu, W., Nasir, K., Schulz, W., Jiang, L., \& Krumholz, H. M. (2018). Association of Body Mass Index with Blood Pressure Among. JAMA Net Open, 1(4), 1-11. https://doi.org/10.1001/jamanetworkopen.2018.1271

Lusiana, N., Widayanti, L. P., Mustika, I., \& Andiarna, F. (2019). Korelasi Usia dengan Indeks Massa Tubuh, Tekanan Darah Sistol-Diastol, Kadar Glukosa, Kolesterol, dan Asam Urat. Journal of Health Science and Prevention, 3(2), 101-108. https://doi.org/10.29080/jhsp.v3i2.242

Malinti, E., \& Elon, Y. (2019). Hubungan Asupan Natrium, Kalium, Indeks Massa Tubuh, Lingkar Pinggang dengan Tekanan Darah Pria Dewasa Muda. Riset Informasi Kesehatan, 8(1), 1-8. https://doi.org/DOI: 10.30644/rik.v8i1.213 Hubungan

Peltzer, K. (2018). The Prevalence and Social Determinants of Hypertension among Adults in Indonesia: A Cross-Sectional Population-Based National Survey. Hindawi International Journal of Hypertension, 2018

Rahma, G. G. (2018). Hubungan Obesitas Sentral dengan Hipertensi pada Penduduk Usia 25-65 Tahun Association of Central Obesity with Hypertension in Population Ages 25- 65 Years. Jurnal Ilmu Kesehatan, 3(2), 118-122

Ramakrishnan, S., Zachariah, G., Gupta, K., Rao, J. S., Mohanan, P. P., Venugopal, K., Sateesh, S., Sethi, R., Jain, D., Bardolei, N., Mani, K., Kakar, T. S., Kidambi, B., Bhushan, S., Verma, S. K., Bhargava, B., Roy, A., Kothari, S. S., Gupta, R., ... Investigators, C. (2019). Prevalence of Hypertension among Indian Adults: Results from the Great India Blood Pressure Survey. Indian Heart Jurnal, 71, 309-313. https://doi.org/10.1016/j.ihj.2019.09.012

Raudhatun, N. (2020). Faktor-Faktor yang Berhubungan dengan Obesitas pada Wanita Usia Subur (WUS) di Wilayah Kerja Puskesmas Darul Imarah Tahun 2020

Riris, O., \& Elon, Y. (2019). Hubungan BMI dengan Kadar Gula Darah pada Wanita Dewasa di Desa Cihanjuang Rahayu. Klabat Jurnal of Nursing, 1(2), 1-7. https://doi.org/https://doi.org/10.37771/kjn.v1i2.405

Roush, G. C. (2019). Obesity-Induced Hypertension: Heavy on the Accelerator. Journal of the American Heart Association, 8(8), 1-2. https://doi.org/10.1161/JAHA.119.012334

Sarma, H., Saquib, N., Hasan, M. M., Saquib, J., Rahman, A. S., Khan, J. R., Uddin, M. J., Cullen, M. R., \& Ahmed, T. (2016). Determinants of Overweight or Obesity among Ever-Married Adult Women in Bangladesh. BMC Obesity, 3(1), 1-11. 
https://doi.org/10.1186/S40608-016-0093-5

Sartika, A., Wardi, A., \& Sofiani, Y. (2018). Perbedaan Efektivitas Progressive Muscle Relaxation (PMR) dengan Slow Deep Breathing Exercise (SDBE) terhadap Tekanan Darah Penderita Hipertensi. Jurnal Keperawatan Silampari, 2(1), 356370. https://doi.org/https://doi.org/10.31539/jks.v2i1.380

Son, W. M., Kim, D. Y., Kim, Y. S., \& Ha, M. S. (2017). Effect of Obesity on Blood Pressure and Arterial Stiffness in Middle-Aged Korean Women. Osong Public Health and Research Perspectives, 8(6), 369-372. https://doi.org/10.24171/j.phrp.2017.8.6.02

Sudikno, S., Syarief, H., Dwiriani, C. M., Riyadi, H., \& Pradono, J. (2017). Hubungan Obesitas Sentral dengan Profil Lipid pada Orang Dewasa Umur 25-65 Tahun di Kota Bogor (Baseline Studi Penyakit Tidak Menular di Kota Bogor, Jawa Barat). Gizi Indonesia, 39(2), 81. https://doi.org/10.36457/gizindo.v39i2.211

Telles, S., Pal, S., Sharma, S. K., Singh, A., Kala, N., \& Balkrishna, A. (2018). The Association Between the Lipid Profile and Fasting Blood Glucose with Weight Related Outcomes in Healthy Obese Adults. BMC Research Notes, 11(1), 1-4. https://doi.org/10.1186/s13104-018-3485-4

Tendean, A. F. (2019). Korelasi Indeks Masa Tubuh (IMT) dengan Tekanan Darah. 3(2), 11-20. https://doi.org/https://doi.org/10.37771/nj.Vol3.Iss2.400

Triyanti, T., \& Ardila, P. (2019). Asupan Lemak Sebagai Faktor Dominan terhadap Obesitas Sentral pada Wanita Fat Intake as a Dominant Factor of Central Obesity Among Women. J. Gipas, 3(November), 133-143

Yaya, S., \& Ghose, B. (2019). Trend in Overweight and Obesity among Women of Reproductive Age in Uganda: 1995-2016. Obesity Science and Practice, 5(4), 312-323. https://doi.org/10.1002/osp4.351

Zahra, H., \& Hadyana, S. R. (2017). Korelasi Indeks Massa Tubuh dengan Profil Lipid pada Masyarakat di Jatinangor Tahun 2014. Jurnal Sistem Kesehatan, 3(1). https://doi.org/https://doi.org/10.24198/jsk.v3i1.13956 